\title{
ANALISIS VARIABILITAS CURAH HUJAN DAN SUHU PADA HUTAN SEKUNDER PT. MELAPI TIMBER
}

\author{
Rainfall Variability and Temperature Analysis of Secondary Forest \\ in Melapi Timber Company
}

\author{
Susanti $^{1 *}$, Prijanto Pamoengkas ${ }^{2}$, Cahyo Wibowo ${ }^{3}$ \\ 1) Mahasiswa pascasarjana Program Studi Silvikutur Tropika, Fakultas Kehutanan IPB. \\ 2) Staf pengajar dan peneliti pada Depertemen Silvikultur, Fakultas Kehutanan IPB. \\ 3) Staf pengajar dan peneliti pada Laboratorium Tanah, Depertemen Silvikultur, \\ Fakultas Pertanian IPB.
}

*Email korespondensi : naina.susanti@gmail.com

\begin{abstract}
The climate is defined as the condition of mean of air temperature, precipitation, the air pressure, the direction of the wind, air moisture and other parameters in long time. The fluctuations of high rainfall significantly affect plant productivity, such as farming, forestry and agriculture. The amount of rainfall is very important in determine the result of the cultivation of plants. Especially if it is associated with the influence of the increase of temperature. The result of this research showed that the type of land at research location were incepticol (land suitability 1) and ultisol (land suitability II, III, IV and V). The mean of annual rainfall in research location (since 2012 until 2014), were 1500 until $2000 \mathrm{~mm} /$ years. The mean air temperature was $26-27^{\circ} \mathrm{C}$ and air moisture between $82-85.9 \%$.
\end{abstract}

Keywords: Melapi Timber, rainfall, temperature, type of land, variability

\section{PENDAHULUAN}

Salah satu faktor lingkungan yang menentukan keberhasilan penanaman adalah iklim. Tanaman yang ditanam di daerah yang tidak sesuai dengan kondisi iklimnya, memiliki tingkat produktivitas yang rendah. Sebaliknya, kondisi iklim yang sesuai akan merangsang pertumbuhan yang baik bagi tanaman. Pada tanaman tahunan, suhu sangat mempengaruhi fase pertumbuhan tanaman. Cekaman (stress) air yang diikuti oleh hujan, umumnya merangsang pembungan tanaman tahunan tropika (Mugnisjah dan Setiawan 1995 dalam Nasution 2009).

Iklim didefinisikan sebagai kondisi rata-rata suhu udara, curah hujan, tekanan udara, arah angin, kelembaban udara dan parameter iklim lainnya dalam jangka waktu yang panjang (Tjasyono 2004).
Indonesia berada di wilayah tropis yang memiliki curah hujan tahunan yang tinggi. Curah hujan semakin tinggi terutama di daerah pegunungan. Curah hujan yang tinggi di wilayah tropis pada umumnya dihasilkan dari proses konveksi dan pembentukan awan hujan panas. Curah hujan konveksi adalah curah hujan yang dihasilkan proses konveksi akibat pemanasan, atau dihasilkan dari proses dinamika seperti konvergensi atau juga dihasilkan akibat terjadi dorongan massa udara secara fisik di lokasi pegunungan (Juaeni 2006).

Fluktuasi curah hujan yang tinggi secara signifikan mempengaruhi produktivitas tanaman, baik tanaman perkebunan, kehutanan dan pertanian. Anwar et al. (2015), jumlah curah hujan secara keseluruhan sangat penting dalam menentukan hasil budidaya tanaman. Terutama jika dikaitkan dengan pengaruh 
peningkatan suhu. Peningkatan curah hujan di suatu daerah berpotensi menimbulkan banjir, sebaliknya jika terjadi penurunan dari kondisi normalnya akan berpotensi terjadinya kekeringan. Kedua hal tersebut, berdampak buruk terhadap metabolisme tubuh tanaman, berpotensi menurunkan produksi dan kegagalan panen.

PT. Melapi Timber merupakan salah satu perusahaan pemegang Ijin Pemanfaatan Hasil Hutan Kayu (IUPHHK) yang sudah beropersi berdasarkan surat keputusan menteri kehutanan nomor: 105/ MENHUT-II/2005. Mempunyai luas areal kerja sebesar $\pm 78,300$ ha. Secara administrasi termasuk ke dalam Kabupaten Kutai Timur dan Kabupaten Kutai Kartanegara, Provinsi Kalimantan Timur. Rencana Kerja Usaha Pemanfaatan Hasil Hutan Kayu dalam Hutan Alam (RKUPHHK-HA) PT. Melapi Timber berbasis Inventarisasi Hutan Menyeluruh Berkala (IHMB). Sistem silvikultur yang digunakan adalah Multisistem Silvikultur. Dimana ada dua sistem silvikultur yang diterapkan, yaitu Tebang Pilih Tanam Indonesia (TPTI) dan Tebang Habis Permudaan Buatan (THPB).

Perlu dilakukan berbagai kajian ggar kegiatan silvikultur ini dapat berjalan dengan baik. Salah satu aspek yang perlu dikaji adalah iklim. Untuk kawasan tropis, aspek iklim yang paling berperan adalah curah hujan dan suhu.

\section{BAHAN DAN METODE PENELITIAN}

\section{Tempat dan Waktu}

Penelitian dilakukan pada areal kerja dan stasiun penangkar curah hujan PT. Melapi Timber Kabuapeten Kutai Kartanegara Provinsi Kalimantan Timur, pada tanggal 22 Oktober 2014 hingga 7 Desember 2014.

\section{Bahan dan Alat}

Bahan dan alat yang digunakan dalam penelitian ini adalah: Peta Areal Kerja PT. Melapi Timber skala 1 : 250.000 tahun 2005, data curah hujan Tahun 2012 hingga 2014, kamera digital dan GPS.

\section{Pelaksanaan Penelitian}

\section{Pengukuran dan Pencatatan Curah Hujan} Harian

Pengukur dan pencatatan curah hujan dilakukan setiap hari pada pukul 08.00 wit. Pengukuran dilakukan menggunakan gelas ukur kemudian dikonversi ke dalam satuan $\mathrm{mm} /$ hari. Data curah hujan 3 (tiga) tahun terakhir diperoleh dari data sekunder milik PT. Melapi Timber.

\section{Penentuan Titik Koordinat dan Elevasi}

Data elevasi digunakan untuk menilai suhu rata-rata $\left(\mathrm{C}^{0}\right)$ lokasi penelitian. Data tersebut diperoleh dari pengambilan titik-titik koordinat pada lokasi penelitian, secara keseluruhan berjumlah 25 contoh. Titik koordinat ditentukan secara purposive sampling atau tidak acak. Ditetapkan secara langsung, setelah berkoordinasi dengan pihak perusahaan dan mempertimbangkan tujuan penelitian. Ketersediaan sarana dan prasarana penunjang (dari dan menuju lokasi penelitian), merupakan pertimbangan penting dalam penentuan titik lokasi tersebut.

\section{Penentuan Suhu Rata-Rata $\left({ }^{\circ} \mathrm{C}\right)$}

Diperkirakan berdasarkan ketinggian tempat dari permukaan laut, menggunakan pendekatan rumus Braak (1982), Djainudin et al. (2000) dalam Hidayat (2006) :

$$
\begin{gathered}
\text { Rata-rata suhu }\left({ }^{\circ} \mathrm{C}\right)=26,3{ }^{\circ} \mathrm{C}-(0,01 \mathrm{x} \\
\text { elevasi dalam meter } \left.\mathrm{x} 0,6{ }^{\circ} \mathrm{C}\right)
\end{gathered}
$$

\section{Penentuan Viabilitas Curah Hujan}

$$
\begin{aligned}
& \text { Untuk menentukan variabilitas } \\
& \text { curah hujan pengamatan digunakan } \\
& \text { parameter berikut (Sauyadhi 2001). }
\end{aligned}
$$

Rata-rata. Rata-rata adalah nilai atau ukuran yang dianggap mewakili suatu kumpulan nilai (variabel curah hujan) yang 
dihitung dengan menjumlahkan semua nilai curah hujan $(x)$ dibagi banyaknya nilai atau jumlah data $(n)$.

$$
(\bar{x})=\sum x / n
$$

Standar Deviasi. Standar deviasi adalah ukuran yang menyatakan seberapa jauh nilai curah hujan menyimpang dari nilai rata-ratanya. Standar deviasi dihitung dengan metoda simpangan baku. Standar deviasi (SD) dihitung dengan rumus:

$$
\mathrm{SD}=\sqrt{\frac{\sum_{i=1}^{n} x i^{2}-\frac{\left(\sum x i\right)^{2}}{n}}{n-1}}
$$

Dimana,

$\mathrm{Xi}=$ Curah hujan bulanan ke-i

$\mathrm{N}=$ Banyaknya tahun

Curah hujan dengan metode simpang baku diklasifikasikan menjadi 5 sifat hujan yakni :

1. Jauh di bawah normal (JBN)

$$
\mathrm{JBN}=\mathrm{x} \leq \mathrm{x}-1.5 \mathrm{SD}
$$

2. Di bawah normal (BN)

$$
\mathrm{BN}=\mathrm{x}-1.5 \mathrm{SD}<\mathrm{x} \leq \mathrm{x}-0.5 \mathrm{SD}
$$

3. Normal (N)

$$
\mathrm{N}=\mathrm{x}-0.5 \mathrm{SD}<\mathrm{x} \leq \mathrm{x}+0.5 \mathrm{SD}
$$

4. Di atas Normal (AN)

$$
\mathrm{AN}=\mathrm{x}+0.5 \mathrm{SD}<\mathrm{x} \leq \mathrm{x}+1.5 \mathrm{SD}
$$

5. Jauh Di atas Normal (JAN)

$$
\mathrm{JAN}=\mathrm{x}>\mathrm{x}+1.5 \mathrm{SD}
$$

Dimana,

$\mathrm{X}=$ Jumlah curah hujan bulanan

$\mathrm{X}=$ Jumlah curah hujan rata-rata bulan yakni jumlah data bulanan tahun $\mathrm{k}$ dibagi dengan banyaknya tahun data

\section{HASIL DAN PEMBAHASAN}

\section{Klasifikasi Tanah}

Berdasarkan hasil pengamatan morfologi, sifat fisik dan kimia tanah, masing-masing pedon memperlihatkan beberapa kesamaan dan perbedaan horison penciri dalam penentuan klasifikasi tanah
$\mathrm{SD}=$ Standard deviasi

Untuk menghitung variabilitas curah hujannya, maka dihitung pula koefisien variasi (KV), yakni standar deviasi yang dibandingkan terhadap ratarata bulanan, dinyatakan dalam persen dan dirumuskan sebagai berikut Conrad (1950) dalam Winarno (1999) :

$$
K V=\frac{\mathrm{SD}}{\mathrm{X}} \times 100 \%
$$

Metode ini telah diterapkan oleh Badan Meteorologi dan Geofisika untuk menentukan sifat curah hujan bulanan di Indonesia (Winarno 1990).

\section{Penentuan Jumlah Bulan Kering, Lembab dan Basah}

Jumlah bulan kering, lembab dan basah ditentukan berdasarkan kriteria Oldeman (1975) dalam Ritung et al. (2007) dan Schmidt dan Ferguson (1951) dalam Setiawan (2012). Berdasarkan kriteria Oldeman: $\mathrm{CH}$ bulan basah > 200 $\mathrm{mm}$, bulan lembab antara $100-200 \mathrm{~mm}$ dan bulan kering $<100 \mathrm{~mm}$. Sedangkan kriteria Schmidt dan Ferguson: bulan basah $(\mathrm{CH}>100 \mathrm{~mm})$, bulan lembab (60 $\mathrm{mm}>\mathrm{CH}<100 \mathrm{~mm}$ ) dan bulan kering $(\mathrm{CH}<60 \mathrm{~mm})$. Dihitung pula musim hujan dan musim kering berdasarkan kriteria BMKG (Oktaviana 2012): musim hujan $\mathrm{CH} \geq 150 \mathrm{~mm} / \mathrm{bln}$ dan musim kering $\mathrm{CH} \leq 150 \mathrm{~mm} / \mathrm{bln}$.

pada lokasi penelitian. Secara keseluruhan pedon pada lokasi penelitian memiliki horison penciri atas ochric (Tabel 1). Hal ini dikarenakan horison terlalu tipis dan tidak dapat dikategorikan sebagai epipedon 
anthropik, folistik, histik, mollik, melanik, plaggen, umbrik, arenik atau grossarenik.

Horison penciri bawah (endopedon) dalam penelitian ini, ditetapkan berdasarkan hasil pengamatan pola sebaran klei. Sebaran klei pada PC 1 menunjukkan adanya horison cambic, dicirikan oleh adanya penimbunan klei tetapi belum memenuhi syarat sebagai horison argilik. Sebaliknya, klei pada PC 3 sampai 6 menunjukkan adanya horison argilic yang dicirikan oleh peningkatan kadar klei iluviasi $>8 \%$ dari kadar eluviasi.

Klasifikasi regim kelembaban tanah pada lokasi penelitian ditetapkan berdasarkan jumlah dan distribusi hujan serta kondisi air tanah. Berdasarkan kriteria Schimid dan Ferguson, rerata bulan kering pada lokasi penelitian adalah 1 bulan/tahun. Dari data tersebut, menunjukkan regim kelembaban tanah pada lokasi penelitian secara umum tergolong udic. Hal ini diperkuat dengan data tahun 1999 - 2008 yang menunjukkan rerata bulan kering sebesar 2.6 bulan/tahun (Winarto 2009). Dilain pihak, pada PC 5 ditemukan adanya bercak karat di kedalaman $80-100 \mathrm{~cm}$ yang menunjukkan regim kelembaban tanah aquic dengan type kejenuhan episaturation.

Tabel 1. Horison penciri dan klasifikasi tanah pada lokasi penelitian

\begin{tabular}{|c|c|c|c|c|c|}
\hline \multirow{2}{*}{ Klasifikasi } & \multicolumn{5}{|c|}{ Pedon/satuan lahan } \\
\hline & PC 1/SL I & PC 3/SL II & PC 4/SL III & PC 5/SL IV & PC 6/SL V \\
\hline Epipedon & Ochric & Ochric & Ochric & Ochric & Ochric \\
\hline Endopedon & Cambic & Argilic & Argilic & Argilic & Argilic \\
\hline $\begin{array}{l}\text { Rejim } \\
\text { kelembaban }\end{array}$ & Udic & Udic & Aquic* & Aquic* & Udic \\
\hline Tanah suhu & \multicolumn{5}{|c|}{--------------- Isohyperthermic --------------- } \\
\hline \multicolumn{6}{|l|}{ USDA } \\
\hline Order & Inceptisosls & Ultisols & Ultisols & Ultisols & Ultisols \\
\hline Sub Order & Udepts & Humults & Humults & Humults & Humulst \\
\hline $\begin{array}{l}\text { Great } \\
\text { group }\end{array}$ & Dystrudepts & $\begin{array}{l}\text { Haplohumult } \\
s\end{array}$ & $\begin{array}{l}\text { Haplohumult } \\
s\end{array}$ & $\begin{array}{l}\text { Haplohumult } \\
s\end{array}$ & $\begin{array}{l}\text { Haplohumult } \\
s\end{array}$ \\
\hline \multicolumn{6}{|c|}{ Modifikasi Dudal \& Soepraptohardjo } \\
\hline Order & & --------- Deng & n perkembanga & profil -------- & 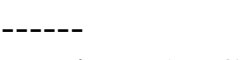 \\
\hline Sub Order & $\begin{array}{l}\text { Horison } \\
A B C\end{array}$ & Horison $\mathrm{ABC}$ & Horison $\mathrm{ABC}$ & Horison $\mathrm{ABC}$ & Horison $\mathrm{ABC}$ \\
\hline $\begin{array}{l}\text { Great } \\
\text { group }\end{array}$ & Kambisol & Podsolik & Podsolik & Podsolik & Podsolik \\
\hline Sub Group & $\begin{array}{l}\text { Kambisol } \\
\text { Oksik }\end{array}$ & $\begin{array}{l}\text { Podsolik } \\
\text { Kandik }\end{array}$ & $\begin{array}{l}\text { Podsolik } \\
\text { Kandik }\end{array}$ & $\begin{array}{l}\text { Podsolik } \\
\text { Ortoksik }\end{array}$ & $\begin{array}{l}\text { Podsolik } \\
\text { Kandik }\end{array}$ \\
\hline
\end{tabular}

Keterangan: *Aquic dengan type kejenuhan Episaturation

Tanah pada SL I atau PC 1 berdasarkan Soil Taxonomy USDA, tergolong ordo Inceptisols dengan sub ordo Udepts dan grup Dystrudepts. Tanah Inceptisol dicirikan dengan ditemukannya horison kambik pada kedalaman 25 sampai $80 \mathrm{~cm}$ dari permukaan tanah. Tanah Inceptisol pada lokasi penelitian tergolong sub ordo Udepts dan grup Dystrudepts (Tabel 1), karena memiliki regim udic dengan kandungan KB $<60 \%$ (Gambar
11). Selanjutnya berdasarkan modifikasi Dudal Soepraptohardjo (1957), SL I tergolong grup Kambisol dengan sub grup Kambisol Oksik. Sub grup Kambisol Oksik dicirikan dengan kadar KTK klei horison B < $24 \mathrm{cmol}_{\mathrm{c}} / \mathrm{kg}\left(\mathrm{NH} 30 \mathrm{~A}_{\mathrm{c}}, \mathrm{pH}\right.$ 7) dengan kedalaman $125 \mathrm{~cm}$ di atas permukaan tanah. Grup Inceptisol/Kambisol ini merupakan jenis tanah yang terluas dari seluruh areal penelitian yaitu sebesar \pm 42 175.09 ha (Tabel 1). 
Satuan lahan lainnya (SL II sampai V) berdasarkan Soil Taxonomy USDA, tergolong ordo Ultisols dengan sub ordo Humults dan grup Haplohumults. Ultisol pada lokasi penelitian dicirikan dengan adanya akumulasi klei $>8 \%$ atau horison argilic. Ultisol pada lokasi penelitian tergolong sub ordo humults karena memiliki C-organik $\geq 0.9 \%$ pada kedalaman $15 \mathrm{~cm}$ dari permukaan teratas horison argilik. Adapun great grupnya tergolong Haplohumults yaitu jenis Humults lain yang tidak termasuk Sombrihumults, Plinthohumults, Kandihumults, Kanhaplohumults atau Palehumults (Tabel 1).

Satuan lahan II sampai V berdasarkan modifikasi Dudal Soepraptohardjo, tergolong grup Podsolik.
Adapun sub grup pada SL II, III dan V, tergolong Podsolik Kandik. Sebaliknya, SL IV tergolong sub grup Podsolik Ortoksik (Tabel 1). Tanah Podsolik pada lokasi penelitian dicirikan dengan adanya horison $\mathrm{B}$ argilik dengan $\mathrm{KB}<50 \%$ dan tidak memiliki horison albik. Podsolik Kandik dicirikan dengan kandungan KTK klei $\mathrm{B}<$ $16 \mathrm{cmol}_{\mathrm{c}} / \mathrm{kg}\left(\mathrm{NH}_{30 \mathrm{~A}_{\mathrm{c}}, \mathrm{pH}}\right.$ 7) pada kedalaman $125 \mathrm{~cm}$ di atas permukaan tanah. Sebaliknya, sub grup Podsolik Ortoksik memiliki kandungan KTK klei B $<24 \mathrm{cmol}_{\mathrm{C}} / \mathrm{kg}$.

Adapun luas masing-masing jenis tanah pada lokasi penelitian, dapat dilihat pada Tabel 2. Luasan ini diperoleh berdasarkan peta unit lahan yang telah digunakan dalam penentuan posisi pengamatan profil tanah.

Tabel 2. Luas dan jenis tanah pada lokasi penelitian

\begin{tabular}{llrrl}
\hline No & \multicolumn{1}{c}{ Jenis tanah } & Luas (ha) & \multicolumn{1}{c}{$\%$} & \multicolumn{1}{c}{ Keterangan } \\
\hline 1 & Inceptisol/Kambisol & $42,175.09$ & 53.86 & SL I \\
2 & Ultisol/Podsolik & $8,398.82$ & 10.72 & SL II, III, IV dan V \\
3 & Lainnya & $27,727.09$ & 35.41 & kawasan PT Melapi \\
& (Hapludults/Dystrudepts) & & & $\begin{array}{l}\text { Timber } \\
\text { bukan/tidak termasuk } \\
\end{array}$ \\
& & & areal penelitian \\
\hline & Jumlah & 78,300 & 100 &
\end{tabular}

Tanah Inceptisol adalah tanah yang telah mengalami proses perubahan bahan induk yang memiliki ciri cukup besar untuk membedakan dengan tanah Entisol, tetapi belum memadai untuk mencirikan jenis tanah lainnya. Kebanyakan Inceptisol memiliki horison kambik (Blankemore et al. 1987 dalam Aydinalp dan FitzPatrick 2003). Inceptisol menempati $40 \%$ dari total daratan Indonesia, yaitu sebesar 70.52 juta ha. Inceptisol merupakan lahan pertanian utama di Indonesia dengan penyebarannya yang cukup luas, diantaranya: Papua 15.49 juta ha, Kalimantan Timur 6.12 juta ha, Kalimantan Tengah 4.21 juta ha dan Maluku 4.0 juta ha (Yuwono 2009). Pemanfaatan tanah Inceptisol sebagai lahan budidaya memerlukan masukan teknologi berupa pemupukan, karena tingkat kesuburan alaminya yang relatif rendah. Hal tersebut ditunjukan dari kandungan $\mathrm{P}$ tersedia yang rendah (Abdurachman et al. 2000).

Tanah yang memiliki horison kambik berdasarkan sistem PPT (1983) dalam Suwandi dan Wiranegara (2000), tergolong Kambisol atau Latosol, dilain pihak berdasarkan Soil Taxonomy termasuk ke dalam Inceptisol. Hardjowigeno (2003), menjelaskan bahwa Kambisol merupakan tanah lain yang mempunyai horison B kambik atau horison A umbrik atau horison A molik tanpa memperlihatkan gejala hidromorfik di dalam penampang $50 \mathrm{~cm}$ dari permukaan. Jenis tanah Kambisol tergolong tanah baru berkembang yang mempunyai potensi untuk pengembangan budidaya (Darmawijaya 1992 dalam Tufaila dan Alam 2014). Kambisol 
umumnya memiliki tekstur yang beragam dari kasar sampai halus yang tergantung pada tingkat pelapukan bahan induknya. Kedalaman efektif tanahnya beragam dari dangkal sampai dalam. Pada dataran rendah kondisi solum tanah umumnya tebal, sebaliknya pada daerah berlereng curam memiliki solum yang tipis (Tufaila dan Alam 2014).

Di lain pihak, Ultisol merupakan salah satu jenis tanah di Indonesia yang mempunyai sebaran luas, mencapai 45.79 juta ha atau sekitar $25 \%$ dari total luas daratan Indonesia (Subagyo et al. 2004). Sebaran terluas terdapat di Kalimantan (21.93 juta ha), diikuti di Sumatera (9.47 juta ha), Maluku dan Papua (8.86 juta ha), Sulawesi (4.30 juta ha), Jawa (1.17 juta ha), dan Nusa Tenggara (53 ribu ha). Tanah Ultisol dalam skala besar telah dimanfaatkan untuk perkebunan kelapa sawit, karet dan hutan tanaman industri.

Namun, pada skala petani kendala ekonomi merupakan salah satu penyebab tidak terkelolanya tanah ini dengan baik (Prasetyo dan Suriadikarta 2006). Ultisol dicirikan oleh adanya akumulasi klei pada horizon bawah permukaan yang

\section{Topografi dan Iklim}

Kelas lereng masing-masing satuan lahan (SL) pada lokasi penelitian, termasuk ke dalam kelas A (0 sampai $8 \%$ ), C (15 sampai $25 \%$ ) dan D (25 sampai $40 \%$ ). Elevasi untuk SL I, II, III dan V berkisar berdampak pada berkurangnya daya resap air dan meningkatkan aliran permukaan serta erosi tanah. Tanah Ultisol mempunyai tingkat perkembangan yang cukup lanjut, dicirikan oleh penampang tanah yang dalam, kenaikan fraksi klei seiring dengan kedalaman tanah, reaksi tanah masam dan kejenuhan basa rendah. Pada umumnya tanah ini mempunyai potensi keracunan $\mathrm{Al}$ dan miskin kandungan bahan organik. Tanah ini juga miskin kandungan hara terutama $\mathrm{P}$ dan kation-kation dapat ditukar seperti $\mathrm{Ca}, \mathrm{Mg}, \mathrm{Na}$ dan $\mathrm{K}$, kadar Al tinggi serta kapasitas tukar kation rendah (Sri dan Mulyadi 1993 dalam Prasetyo dan Suriadikarta 2006).

Tanah Ultisol berdasarkan klasifikasi

Dudal \& Soepraptohardjo (1957), umumnya diklasifikasikan sebagai Podsolik. Jenis tanah Podsolik merupakan jenis tanah yang tergolong miskin unsur hara dan bereaksi masam. Kesuburan alami tanah ini hanya tergantung pada lapisan atas bahan organik (Munir 1996 dalam Tafaila dan Alam 2014), namun penampang tanahnya masih cukup dalam dan berkadar kleinya tinggi.

antara 101 sampai $155 \mathrm{~m}$ dari permukaan laut (dpl). Satuan lahan IV memiliki elevasi terendah, yaitu 64 sampai $67 \mathrm{~m}$ dpl. Rerata suhu udara pada lokasi penelitian, berdasarkan rumus Braak (1928) berkisar antara 25.35 sampai $25.91{ }^{\circ} \mathrm{C}$ (Tabel 3).

Tabel 3. Titik koordinat lokasi penelitian, elevasi, suhu dan kelas lereng

\begin{tabular}{|c|c|c|c|c|c|c|c|}
\hline \multirow{2}{*}{$\begin{array}{l}\text { Satuan } \\
\text { lahan }\end{array}$} & \multirow{2}{*}{ Kode } & \multirow{2}{*}{$\begin{array}{c}\text { Profil } \\
\text { tanah/ } \\
\text { Ulangan }\end{array}$} & \multicolumn{2}{|c|}{ Titik koordinat } & \multirow{2}{*}{$\begin{array}{l}\text { Elevasi } \\
\text { (m dpl) }\end{array}$} & \multirow{2}{*}{$\begin{array}{c}\text { Suhu } \\
\left({ }^{\circ} \mathrm{C}\right)\end{array}$} & \multirow{2}{*}{$\begin{array}{l}\text { Kelas } \\
\text { lereng }\end{array}$} \\
\hline & & & Bujur & Lintang & & & \\
\hline \multirow{5}{*}{ I } & \multirow{5}{*}{ PC1 } & 1 & $116^{\circ} 13^{\prime} 30^{\prime \prime}$ & $0^{\circ} 39^{\prime} 10^{\prime \prime}$ & 105 & 25.66 & \multirow{5}{*}{$\begin{array}{c}\text { A }(0-8 \%) \\
\text { datar }\end{array}$} \\
\hline & & 2 & $116^{\circ} 13^{\prime} 30^{\prime \prime}$ & $0^{\circ} 39^{\prime} 11^{\prime \prime}$ & 101 & 25.68 & \\
\hline & & 3 & $116^{\circ} 13^{\prime} 29$ ' & 0'39'09" & 105 & 25.66 & \\
\hline & & 4 & $116^{\circ} 13^{\prime} 29$ "' & 0'39'07' & 109 & 25.64 & \\
\hline & & 5 & $116^{\circ} 13^{\prime} 31^{\prime \prime}$ & 0'39'07' & 111 & 25.62 & \\
\hline \multirow{5}{*}{ II } & & 1 & $116^{\circ} 14^{\prime} 39^{\prime \prime}$ & $0^{\circ} 40^{\prime} 35^{\prime \prime}$ & 133 & 25.49 & \multirow{5}{*}{$\begin{array}{c}\text { A }(0-8 \%) \\
\text { datar }\end{array}$} \\
\hline & & 2 & $116^{\circ} 14^{\prime} 39^{\prime \prime}$ & $0^{\circ} 40^{\prime} 34^{\prime \prime}$ & 125 & 25.54 & \\
\hline & PC3 & 3 & $116^{\circ} 14^{\prime} 38^{\prime \prime}$ & $0^{\circ} 40^{\prime} 35^{\prime \prime}$ & 140 & 25.45 & \\
\hline & & 4 & $116^{\circ} 14^{\prime} 38^{\prime \prime}$ & $0^{\circ} 40^{\prime} 34^{\prime \prime}$ & 141 & 25.44 & \\
\hline & & 5 & $116^{\circ} 14^{\prime} 40^{\prime \prime}$ & $0^{\circ} 40^{\prime} 34^{\prime \prime}$ & 136 & 25.47 & \\
\hline
\end{tabular}




\begin{tabular}{|c|c|c|c|c|c|c|c|}
\hline \multirow{5}{*}{ III } & \multirow{5}{*}{ PC4 } & 1 & $116^{\circ} 10^{\prime} 04^{\prime \prime}$ & $0^{\circ} 36^{\prime} 11^{\prime \prime}$ & 134 & 25.48 & \multirow{5}{*}{$\begin{array}{c}\text { A }(0-8 \%), \\
\text { datar }\end{array}$} \\
\hline & & 2 & $116^{\circ} 10^{\prime} 04^{\prime \prime}$ & $0^{\circ} 36^{\prime} 12^{\prime \prime}$ & 155 & 25.35 & \\
\hline & & 3 & $116^{\circ} 10^{\prime} 04^{\prime \prime}$ & $0^{\circ} 36^{\prime} 13^{\prime \prime}$ & 137 & 25.46 & \\
\hline & & 4 & $116^{\circ} 10^{\prime} 05^{\prime \prime}$ & $0^{\circ} 36^{\prime} 12^{\prime \prime}$ & 140 & 25.45 & \\
\hline & & 5 & $116^{\circ} 10^{\prime} 05^{\prime \prime}$ & $0^{\circ} 36^{\prime} 11^{\prime \prime}$ & 152 & 25.37 & \\
\hline \multirow{5}{*}{ IV } & \multirow{5}{*}{ PC5 } & 1 & $116^{\circ} 09^{\prime} 09^{\prime \prime}$ & $0^{\circ} 35^{\prime} 32^{\prime \prime}$ & 67 & 25.89 & \multirow{5}{*}{$\begin{array}{l}\mathrm{C}(15-25) \text {, } \\
\text { agak curam }\end{array}$} \\
\hline & & 2 & $116^{\circ} 09^{\prime} 09^{\prime \prime}$ & $0^{\circ} 35^{\prime} 30^{\prime \prime}$ & 64 & 25.91 & \\
\hline & & 3 & $116^{\circ} 09^{\prime} 09^{\prime \prime}$ & $0^{\circ} 35^{\prime} 31^{\prime \prime}$ & 64 & 25.91 & \\
\hline & & 4 & $116^{\circ} 09^{\prime} 10^{\prime \prime}$ & $0^{\circ} 35^{\prime} 31^{\prime \prime}$ & 64 & 25.91 & \\
\hline & & 5 & $116^{\circ} 09^{\prime} 10^{\prime \prime}$ & $0^{\circ} 35^{\prime} 32^{\prime \prime}$ & 65 & 25.90 & \\
\hline \multirow{5}{*}{$\mathrm{V}$} & \multirow{5}{*}{ PC6 } & 1 & $116^{\circ} 08^{\prime} 17^{\prime \prime}$ & $0^{\circ} 34^{\prime} 23^{\prime \prime}$ & 108 & 25.64 & \multirow{5}{*}{$\begin{array}{l}\mathrm{D}(25-40 \\
\%), \text { curam }\end{array}$} \\
\hline & & 2 & $116^{\circ} 08^{\prime} 17^{\prime \prime}$ & $0^{\circ} 34^{\prime} 24^{\prime \prime}$ & 111 & 25.62 & \\
\hline & & 3 & $116^{\circ} 08^{\prime} 16^{\prime \prime}$ & $0^{\circ} 35^{\prime} 24^{\prime \prime}$ & 105 & 25.66 & \\
\hline & & 4 & $116^{\circ} 08^{\prime} 16^{\prime \prime}$ & $0^{\circ} 35^{\prime} 23^{\prime \prime}$ & 112 & 25.62 & \\
\hline & & 5 & $116^{\circ} 08^{\prime} 15^{\prime \prime}$ & $0^{\circ} 35^{\prime} 23^{\prime \prime}$ & 111 & 25.62 & \\
\hline
\end{tabular}

Rerata $\mathrm{CH}$ tahunan pada lokasi penelitian (2012 sampai 2014), berkisar antara 1500 sampai $2000 \mathrm{~mm} /$ tahun. CH tertinggi berkisar antara 189 sampai 267 mm pada bulan April dan Desember, terendah $<65 \mathrm{~mm} /$ bulan terjadi antara September dan Oktober. Tahun 2014 terdapat penurunan dan kenaikan $\mathrm{CH}$ yang ekstrim, dimana $\mathrm{CH}$ terendah mencapai 22

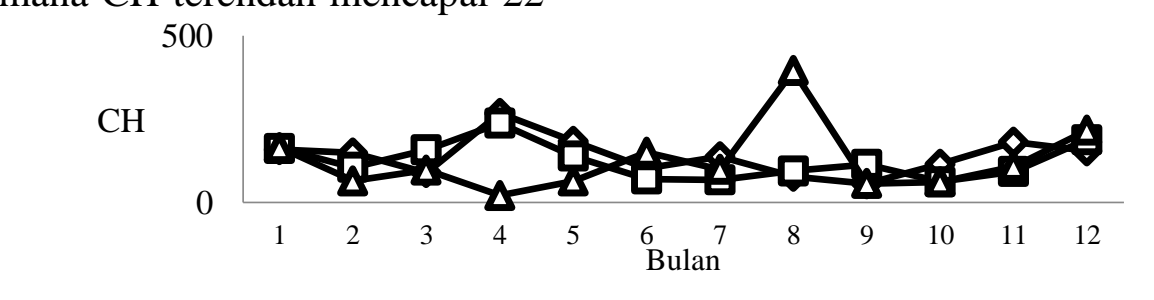

mm dan tertinggi $395 \mathrm{~mm}$. $\mathrm{CH}$ tertinggi tersebut, terjadi pada bulan Agustus dan langsung turun dengan ekstrim pada bulan September dan Oktober 2014 (57 sampai $62 \mathrm{~mm} /$ bulan) (Gambar 1). Berdasarkan data tersebut, diketahui bahwa tipe pola hujan pada lokasi penelitian termasuk ke dalam pola ekuatorial.

Gambar 1. Curah hujan rerata $(\mathrm{mm}) \multimap$ Tahun $2012 \neg-\square 2013-\Delta 2014$

Bulan kering (BK) pada lokasi penelitian, berdasarkan Schmidt dan Ferguson rerata terjadi 1 bulan/tahun.
Berdasarkan klasifikasi BMKG, rerata musim hujan 8 bulan/tahun dan musim kering 4 bulan/tahun (Tabel 4).

Tabel 4. Jumlah bulan basah, lembab dan kering serta musim hujan dan kering tahun 2012 sampai 2014

\begin{tabular}{ccccccl}
\hline \multirow{2}{*}{ Klasifikasi } & $\mathrm{CH}$ & \multicolumn{3}{c}{$\begin{array}{c}\text { Jumlah } \\
\text { (bulan/tahun) }\end{array}$} & $\begin{array}{c}\text { Rerata } \\
\text { (bulan/tahun }\end{array}$ & Keterangan \\
\cline { 2 - 5 } & (mm/bulan) & 2012 & 2013 & 2014 & ) & \\
\hline Schmidt dan & $>100$ & 9 & 7 & 5 & 7 & Bulan basah \\
Ferguson & $60-100$ & 2 & 5 & 5 & 4 & Bulan lembab \\
& $<60$ & 1 & 0 & 2 & 1 & Bulan kering \\
BMKG & $\geq 150$ & 5 & 4 & 4 & 4 & Musim hujan \\
& $\leq 150$ & 7 & 8 & 8 & 8 & Musim kering \\
\hline
\end{tabular}

Secara geografis lokasi penelitian terletak di antara $115^{\circ} 59^{\prime} 00^{\prime \prime}$ sampai $00^{\circ} 53^{\prime} 00^{\prime}$ 'LU. Secara umum suhu udara 
pada lokasi penelitian, minimum 22.10 sampai $23.10{ }^{\circ} \mathrm{C}$ dan maksimum 30.90 sampai $31.90{ }^{\circ} \mathrm{C}$. Suhu udara rerata 26 sampai $27{ }^{\circ} \mathrm{C}$ dan kelembaban udara antara 82 sampai $85.9 \%$ (Winarto 2014).

Tipe pola hujan pada lokasi penelitian termasuk ke dalam pola ekuatorial. Tukidi (2010), menjelaskan bahwa secara umum wilayah Indonesia di sekitar ekuator dicirikan dengan musim kemarau yang singkat dan musim hujan yang panjang, serta dua kali maksimum $\mathrm{CH}$ bulanan dalam setahun. Musim kemarau secara berangsur-angsur akan lebih panjang untuk wilayah yang lebih

\section{KESIMPULAN}

Jenis tanah pada lokasi penelitian adalah incepticol (SL 1) dan ultisol (SL II, III, IV, V). Rerata CH tahunan pada lokasi penelitian (2012 sampai 2014), berkisar antara 1500 sampai $2000 \mathrm{~mm} /$ tahun. Suhu udara rerata 26 sampai $27{ }^{\circ} \mathrm{C}$ dan kelembaban udara antara 82 sampai 85.9 $\%$.

\section{DAFTAR PUSTAKA}

Abdurachman A. Dariah A. Mulyani A. 2000. Strategi dan teknologi pengelolaan lahan kering mendukung pengadaan pangan nasional. $J$. Litbang Pertanian. 27 (2): 43 - 9

Aydinalp C. Fitzpatric EA. 2003. Genesis and clasification of inceptisols formed on the slate parent material under forest vegetation. $J$ Central European Agriculture. 4 (4): 281 286

Dudal R. Soepraptohardjo M. 1957. Soil Clasification in Indonesia. Bogor (ID): Cont. Agr. Sta. No. 148

Hardjowigeno S. 2003. Klasifikasi Tanah dan Pedogenesis edisi revisi. Jakarta (ID): Akademika Pressindo

Hidayat MY. 2006. Kesesuaian satuan lahan untuk tanaman sengon jauh dari garis ekuator ke arah selatan dan tenggara. Pola ekuatorial merupakan tipe pola hujan yang yang memiliki 2 (dua) kali maksimum $\mathrm{CH}$ bulanan dalam kurun waktu setahun disebut memiliki pola bimodal (Gambar 1). Di Indonesia, $\mathrm{CH}$ yang mengikuti pola ini terjadi di sebagian besar wilayah Sumatra dan Kalimantan. KFCP (2014), menjelaskan bahwa data tersebut penting untuk penentuan waktu tanam yang tepat. Waktu penanaman pohon yang baik disarankan pada awal musim hujan atau akhir musim kemarau untuk menghindari kekeringan.

(Paraserianthes falcataria (L) Nielsen) pada beberapa satuan kelas lereng (studi kasus di Kecamatan Cipatat, Kabupaten Bandung, Jawa Barat) [skripsi]. Bogor (ID): Program Studi Budidaya Hutan Fakultas Kehutanan IPB

Mugnisjah WQ, Setiawan A. 1995. Produksi Benih. Jakarta(ID): Penerbit Bumi Aksara Jakarta

Prasetyo BH. Suryadikarta DA. Karakteristik, potensi dan teknologi pengelolaan tanah ultisol untuk pengembangan pertanian lahan kering di Indonesia. J. Litbang Pertanian. 25 (2): $39-46$

Ritung S, Wahyunto, Agus F, Hidayat. 2007. Panduan Evaluasi Kesesuaian Satuan Lahan: dengan contoh peta arahan penggunaan satuan lahan kabupaten Aceh Barat. Bogor (ID): Balai Penelitian Tanah dan World Agroforestry Center

Ritung S, Nugroho K, Mulyani A, Suryani E. 2011. Petunjuk Teknis Evaluasi Lahan untuk Komuditas Pertanian. Bogor (ID): Balai Besar Penelitian dan Pengembangan Sumberdaya Lahan Pertanian, Balai Penelitian dan Pengembangan Pertanian

Subagyo H. Suharta N. Siswanto AB. 2004. Tanah-tanah Pertanian di 
Indonesia. hlm. 21-66. dalam A. Adimihardja LI, Amien F, AD. Djaenudin (Ed.). Sumberdaya Lahan Indonesia dan Pengelolaannya. Bogor (ID): Pusat Penelitian dan Pengembangan Tanah dan Agroklimat

Suwandi, Wiranegara H. 2000. Penuntun Praktikum Morfologi dan Kasifikasi Tanah. Bogor (ID): Jurusan Tanah, Fakultas Pertanian Institut Pertanian Bogor

Tufaila M, Alam S. 2014. Karakteristik tanah dan evaluasi lahan untuk pengemangan tanaman padi sawah di Kecamatan Oheo Kabupaten Konawe Utara. J. Agriplus. 24 (2): 184 - 194

Winarto S. 2014. Rencana Kerja Usaha Pemanfaatan Hasil Hutan Kayu dalam Hutan Alam pada Hutan Produksi berbasis IHMB Periode 2014 - 2023. Samarinda (ID): PT Melapi Timber

Yuwono NW. 2009. Membangun Kesuburan tanah di lahan marginal. J. Tanah dan Lingkungan. 9 (2): 137 $-41$ 